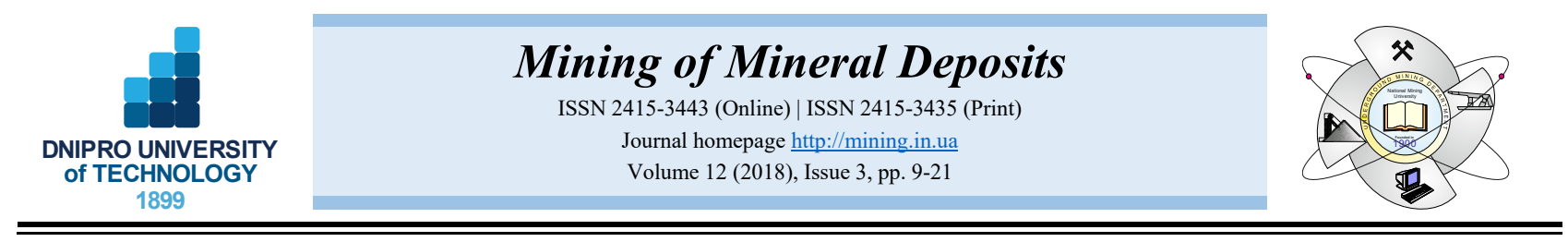

UDC 622.023 .23

https://doi.org/10.15407/mining12.03.009

\title{
SIMULATION OF SAMPLE TESTING UNDER COMPRESSION WITH THE HELP OF FINITE-ELEMENT MODEL OF ROCKS BEING BROKEN
}

\author{
A. Olovyannyy ${ }^{1 *}$, V. Chantsev² \\ ${ }^{1}$ Saint-Petersburg Branch of the Federal State Budgetary Institution of Science of the Institute of Geoecology named after \\ E.M. Sergeev of the Russian Academy of Sciences, Saint-Petersburg, Russian Federation \\ ${ }^{2}$ Peter the Great Saint-Petersburg Polytechnic University, Saint-Petersburg, Russian Federation \\ *Corresponding author: e-mail agolov2009@hgepro.ru, tel.+79500033165
}

\begin{abstract}
Purpose of the paper is to develop mathematical model describing nature of argillous and salt samples under compression and to make available microdefects using finite-element method.

Methods. To simulate behaviour of cylindrical rock samples under axial strain, finite-element model of rocks, being broken, is applied. In terms of the assumed model, components of medium with the disturbed continuity are calculated as those being continuous with anisotropic deformational and strength properties. Failure is considered as strength loss in terms of displacement and tensile on the anisotropy planes of the element. Within each point of the medium (if finite-element method is applied, then each element is meant) the limited number of planes of possible failure with $45^{\circ}$ pitch is considered; they are used within each stage to evaluate potential failure resulting from displacement stresses or tensile ones. Coulomb-Mohr criteria as well as tensile strength are applied to determine potential failure on sites.

Findings. It has been determined that mathematical modeling enables observing the process of disturbances within the sample. Stress-deformation diagrams, being a result of the modeling, demonstrate features of the sample behaviour during different loading stages (i.e. nonlinear nature up to the peak load; decrease while breaking; residual strength; and hysteresis loops in terms of cyclic loading). It has been proved that if the model parameters are selected adequately, acceptable coincidence of both calculated and laboratory curves describing connections of axial strains and side strains with pressure on the samples of clay, sylvinite, and rock salt can be achieved.

Originality. Finite-element has been developed. The model makes it possible to describe processes of strain and failure of rock samples in the context of laboratory tests; moreover, the model differs in the fact that it is added by the description of deformation processes taking place in microfissures and pores.

Practical implications. Modeling with the use of finite-element method for rocks under breaking helps reach sufficient coincidence of the calculated diagrams of sample tests with graphs of stresses-deformations connection resulting from the laboratory studies. The obtained positive results confirm applicability of finite-element model of rock deformation and failure in terms of rock pressure problems.
\end{abstract}

Keywords: rock, samples, deformation, failure, deformation of pores, mathematical modeling, finite-element method

\section{INTRODUCTION}

The samples, analyzed under laboratory conditions, are the share of rock mass undisturbed by such discontinuities as foliation and large fissures. Common laws of motion act both in samples and in rock masses. Laboratory studies for rock samples are aimed at the determination of parameters of deformation and strength properties used for engineering analysis.

Most of all, cylindrical samples are used to analyze deformation and strength properties of rock under laboratory conditions (Kartashov, Matveev, Mikheev, \& Fadeev,
1979; Stavrogin \& Tarasov, 1992). Pressure is put on samples by means of axial and side loads at different velocities. Figure 1 demonstrates results of tests carried out with the use of rock salt sample (Kartashov, Matveev, Mikheev, \& Fadeev, 1979). Cylindrical sample with $36 \mathrm{~mm}$ diameter and $70 \mathrm{~mm}$ height was tested when axial deformation velocity was $0.2 \mathrm{~mm} / \mathrm{min}$. Researchers paid attention to following effect: elasticity modulus, determined on axial strains in the process of the sample unloading, varied insignificantly within rather wide load range. 
(a)

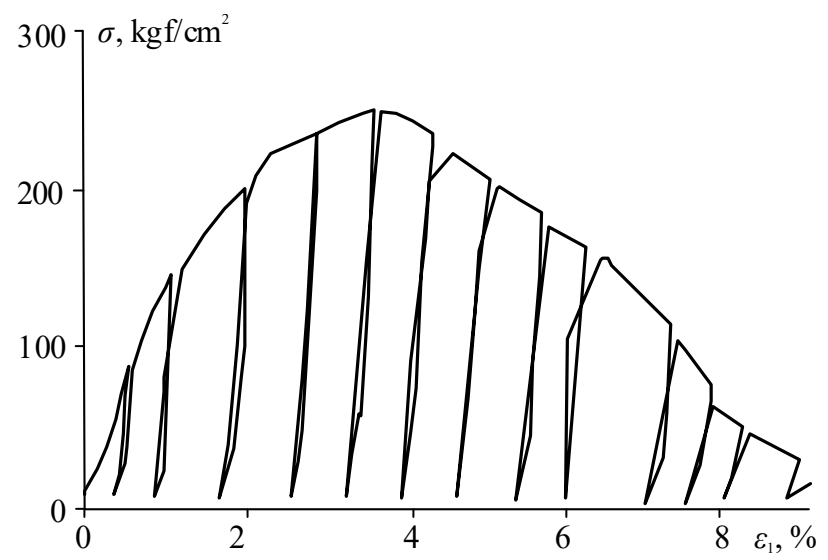

(b)

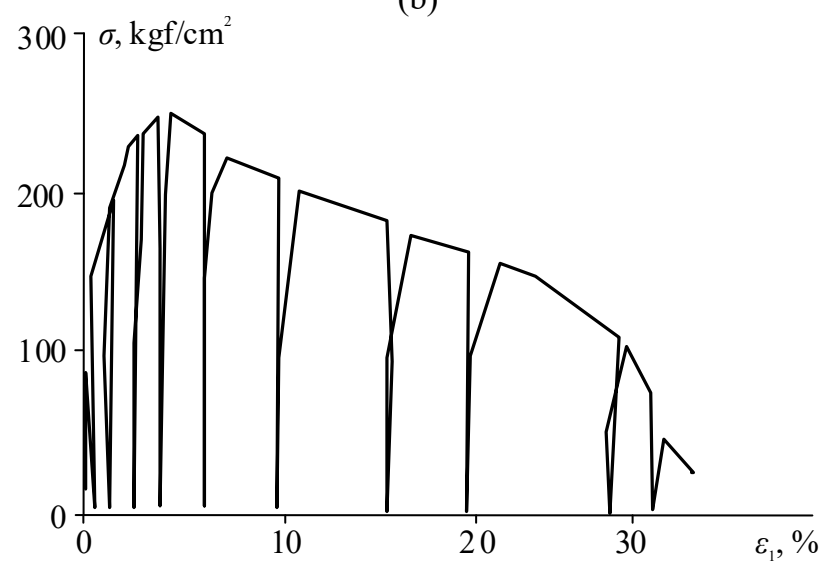

Figure 1. The development of axial (a) and side strains (b) in rock salt samples in terms of cyclical uniaxial compression (Kartashov, Matveev, Mikheev, \& Fadeev, 1979)

From the starting loading point to destruction point $\left(25 \cdot 10^{3} \mathrm{MPa}\right)$ and after the sample destruction (up to the load being almost $60 \%$ of compression strength), elasticity moduli can be practically considered as constant ones. In the process of further deformation, elasticity moduli experience their $2-3$ times decrease (Fig. 1a). A form of lateral deformation curve (Fig. 1b) is asymmetrical: side strains increase sharply after peak loading since microfissures within the sample material becomes opened and its volume increased. Initial nonlinear section of longitudinal deformation graph reflects effect of microfissures and pores.

Elastic and elastic-plastic models are applied to solve the problems of mine working stability. To estimate destruction zones, numerical calculations (finite-element method or net method) use criteria determining failure (plasticity) conditions in terms of stress state invariants; review of the criteria can be found in the paper (Pan \& Hudson, 1989). Experimental studies of failure mechanism under sample compression are discussed extensively in following papers (Wawersik \& Fairhurst, 1970; Wawersik \& Brace, 1971; Lockner, Byerlee, Kuksenko, Ponomarev, \& Sidorin, 1991; Cox \& Meredith, 1993; Pells, 1993). Formulation of conditions of incipient displacement and fracture planes as well as their planes is required to substantiate the techniques to simulate geo- mechanical processes within rock masses. Various constitutive models have been proposed to simulate potent behaviour of geomaterials (Walsh \& Brace, 1964; Pariseau, 1968; Hoek \& Brown, 1980; Nova, 1980; Pietruszczak \& Mroz, 2001; Chiarelli, Shao, \& Hoteit, 2003; Lydzba, Pietruszczak, \& Shao, 2003; Shao, Jia, Kondo, \& Chiarelli, 2006; Hoxha, Giraud, Homand, \& Auvray, 2007; Lee \& Pietruszczak, 2008; Shen \& Shao, 2017).

Basically, strength criteria are approximation of boundary surface of failure conditions within stress space for initially uniform material. So-called zones of plastic deformations and failures in the neighbourhood of mine workings and engineering structures are calculated with the help of such criteria. Hoek-Brown criterion (Hoek \& Brown, 1980) and its modifications are the most popular ones.

Finite-element method is widely used in the process of rock pressure problems calculation (Fadeev, 1987). During the last two decades, discrete elements method and such mixed methods as hybrid finite-element model (Lisjak, Figi, \& Grasselli, 2014) became rather popular. In terms of such models, calculation area is considered as that consisting of either rigid or elastic elements separated by contact surfaces within which plastic deformations and failure are possible.

Nonlinear character of initial section of the axial strain diagram (Fig. 1) confirms availability of such microdefects as pores and fissures. Rock microdefects effect on the deformation processes lowering the strength. In the context of crystalline rocks, microfissures are divided into two groups: natural microfissures being formed as a result of natural processes including changes in pressure or temperature during geological time; and stress induced (i.e. mechanically induced) microfissures depending upon changes in stresses and their concentrations in the process of drilling and other operations (Nur \& Simmons, 1970). Paper (Hamdi, Stead, \& Elmo, 2015) proposes to use combined method of discrete and finite elements inclusive of micro-discrete model of fissure system $(\mu \mathrm{DFN})$. Many authors (Tang, Liu, Lee, Tsui, \& Tham, 2000; Tang, Tham, Lee, Tsui, \& Liu, 2000; Fang \& Harrison, 2002) consider microdefects as nonuniform impurities with deviations from strength and elastic properties. Such methods cannot involve moments of microfissure and pore closure.

The paper exemplifies simulation of rock samples in terms of uniaxial compression with the use of a model of rocks under failure (Olovyannyy, 2003; Olovyannyy, 2012). The model uses finite-element method. Within each element, the material is being considered as continuous and uniform where plastic deformations and failure initiate differently oriented anisotropy. Limited number of oriented anisotropy planes with $45^{\circ}$ step is separated; the planes are those where shear fracture or disruptive fracture is possible. As distinct from models with contact surfaces, where fracture happens on the contacts of uniform elements, in the context of the model, fracture is simulated as that distributed on the strength weakening and plane discontinuity like in a laminal formation. Since, such structures are disturbed on their planes then Coulomb-Mohr share strength criterion and tensile strength criterion are used to estimate potential increase 
in plastic deformations and disturbances. The model takes into consideration the possibility of simultaneous rise of several anisotropy planes and changes in their parameters within varying stress fields and time.

Effect of microdefects (i.e. pores and microfissures) is considered at a phenomenological level. Equations, describing deformation processes of the microstructure, are based upon the agreement between experimental and theoretical graphs, namely axial strains - stresses and axial strains - side strains.

Mathematical modeling of rock samples behaviour under the conditions, simulating laboratory tests, makes it possible to verify the model approximations and to specify them while comparing theoretical and experimental results. Results of the modeling help determine parameters of equations of state which correctness is confirmed while comparing theoretical and laboratory graphs of a sample deformation.

Scientific sources exemplify simulation with the use of various models when a zone with rectangular section is being deformed in terms of a plane deformation (Unteregger, Fuchs, \& Hofstetter, 2015). There are also examples of cylindrical samples modeling under axial compression with the use of analytical solutions in a theory of plastic potential under the ideal loading conditions (Unteregger, Fuchs, \& Hofstetter, 2015).

Results of the laboratory tests, when uniaxial compression was used, are dependence graphs of a sample pressure on axial and side strains. In the context of mathematical modeling of a sample testing, dependence between a sample pressure and deformations is also graphed. A type of the graphs depends upon the taken parameters of the equations of a state of rock behaviour. If the model of a sample behaviour reflects correctly the regularities of elastic, plastic, and viscous deformation as well as destruction within the rock, then such a selection of a state equation parameters is possible when the design graphs will match experimental curves.

\section{A MODEL OF ROCK FAILURE ACCORDING TO THE ORIENTED DIRECTIONS}

Lithospheric defects are of various dimensions and orientation. Such large defects as faults, dividing rock masses into parts, may be considered as separate objects. Fissures, existing in rocks, and those, arising in the neighbourhood of mine workings, form differently oriented systems. It is impossible to describe each existing or newly formed fissure as well as to consider it while modeling. Similar situation arises when rock samples are being faulted. It is also impossible to take into consideration the origination of each sample defect in the modeling process.

To model behaviour of the loaded samples, use a method of failure consideration within the medium elements on the fixed directions by analogy with continuum material with the oriented anisotropy planes (Olovyannyy, 2003; Olovyannyy, 2012). In the process of modeling, destructive medium is considered to be continuum during each deformation stage; it is described with the help of continuum mechanics equations. In terms of such a medium, the surfaces subjecting to failure cannot be considered as separate objects. The failure is interpreted as the decrease in the elements strength on the oriented directions.
According to the proposed scheme of the infinite number of possible planes of fissure formation, directions with $45^{\circ}$ step are considered. In general case, (i.e. in 3D space), there are 13 directions of such a type.

Solution method with axial symmetry conditions is applied while sample simulating. Nine line of weakness (i.e. anisotropy planes) are separated in the context of axial symmetry (Fig. 2). In the Figure, every of the systems (i.e. planes) is shown with the help of three or four identical numbers: $1-1-1,2-2-2,3-3-3-3$, $4-4-4,5-5-5,6-6-6-6,6^{\prime}-6^{\prime}-6^{\prime}, 7-7-7-7$, and $7^{\prime}-7^{\prime}-7^{\prime}$ respectively. On systems $1,2,3,4$, and 5, deformation may take place irrespectively of each other. Systems 6 and $6^{\prime}$ within radial inclined directions, and vertical paired systems 7 and $7^{\prime}$ deviate from $r-z$ plane (in this context, $r$ is radial coordinate, and $z$ is coordinate along the symmetry axis) at identical angles to and fro. If deformation takes place along $6-6^{\prime}$ directions, then weakening rise to a lateral surface of a sample are demonstrated by means of inclined Luders lines; disturbances towards 7 and $7^{\prime}$ directions form spirals within $z=$ const planes.

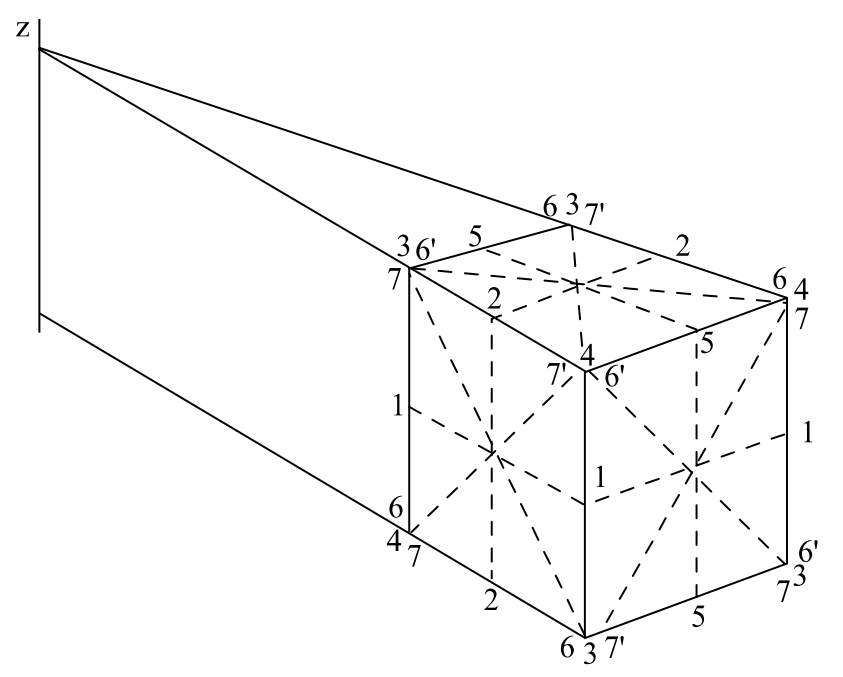

Figure 2. Scheme of the fixed directions of potential fracture networks (laminal formations) in the context of axisymmetrical deformation

Numerical modeling involves finite-element method basing upon mechanics of linear and deforming medium. Such nonlinear effects as plastic and viscous deformations are solved with the help of a procedure of fictious nodal forces (Fadeev, 1987). Each step calculations within each element determine stresses acting at sites of each of the separated planes. Within each site, possibility of shear failure or fissure failure is estimated; to do that, corresponding criteria (i.e. Coulomb-Mohr criterion and tensile strength criterion) are applied:

$$
\begin{aligned}
& \left|\tau_{n}\right|=C+\sigma_{n} \operatorname{tg} \phi, \sigma_{n}>0 ; \\
& \sigma_{n}=\sigma_{t}, \sigma_{n}<0,
\end{aligned}
$$

where:

$\sigma_{n}$ and $\tau_{n}$ - normal and tangential stresses within the site;

$C$-adhesion;

$\sigma_{t}$ - tensile strength. 
Strength condition (1) will be broken during certain deformation stage; then, the strength degradation will take place within the corresponding plane. Thus, adhesion and tensile strength will be equal to $p_{n} C$ and $p_{n} \sigma_{t}$ respectively; in this context, $p_{n} \leq 1$ determines degradation index. Hence, strength conditions are:

$$
\begin{aligned}
& \left|\tau_{n}\right|=p_{n} C+\sigma_{n} \operatorname{tg} \phi, \sigma_{n}>0 ; \\
& \sigma_{n}=p_{n} \sigma_{t}, \sigma_{n}<0,
\end{aligned}
$$

where:

$p_{n}$-degradation index determines strength share within undisturbed rock;

$p_{n}=1$ for solid (undisturbed) formation;

$0<p_{n}<1$ for the formation with the weakened strength;

$p_{n}=0$ in terms of total strength loss.

Calculation procedure is as follows: tangential and normal stresses as well as elastic and nonelastic deformations are calculated within each element on each of the separated directions after stress field was determined. To estimate conditions within the sites with $\vec{n}$ normal, relative intensity of shear $\left(c_{\tau}\right)$ and tension $\left(c_{t}\right)$ are calculated in accordance with condition (2). Their values may be 0 to 1 :

$$
\begin{aligned}
& c_{\tau}=\frac{\left|\tau_{n}\right|}{C p_{n}+\sigma_{n} \operatorname{tg} \phi} ; \\
& c_{t}=\left\{\begin{array}{l}
\frac{\sigma_{n}}{\left(p_{n} \sigma_{t}\right)} \text { if } \sigma_{n}<0 ; \\
0 \text { if } \sigma_{n}>0 .
\end{array}\right.
\end{aligned}
$$

If $c_{\tau}>c_{l}$, then deformation of plastic displacement increases and adhesion in addition to tensile strength $p_{n}$ decreases within the element corresponding to the direction. In this context, $c_{l}$ is long-time strength coefficient being determined by means of elastic limit stress-strength limit ratio. If within $c_{l}<c_{\tau}<1$ site stresses are not peak ones, then plastic deformations are limited. In terms of a sample, such a situation corresponds to nonlinear section of load diagram up to its maximum. Within the considered site the limitation is formulated by $\left|\gamma^{p}\right|<K_{p l}\left|\gamma^{e}\right|$ condition. In this context, $K_{p l}$ is plasticity coefficient determining the ratio between plastic deformation and elastic one in terms of maximum pressure; and $\gamma$ is elastic shear deformation. Following dependence of plastic deformation on a load degree has been taken for the stage:

$$
\gamma^{p}=K_{p l} \gamma^{e}\left\{\frac{c_{\tau}-c_{l}}{1-c_{l}}\right\}^{2} \text {, if } c_{\tau}>c_{l}, \gamma^{p}<K_{p l}\left|\gamma^{e}\right| \text {. }
$$

If $\left|\gamma^{p}\right|>K_{p l}\left|\gamma^{e}\right|$ and $c_{\tau}>c_{l}$ (within decreasing site) plastic deformations are limited by environmental effect only.

In terms of $c_{\tau}>c_{l}$, shear increment is determined towards tangential stresses and loosening deformation normally to the anisotropy plane:

$$
\Delta \gamma_{n}^{p}=\delta ; \Delta \varepsilon_{n}^{p}=-K_{v} \delta,
$$

where:

$$
\begin{aligned}
& \delta \text { - small value; } \\
& K_{v} \text { - fragmentation coefficient. }
\end{aligned}
$$

If $c_{\tau}<c_{l}$, then plastic displacements and failures do not increase. If $c_{\tau}>c_{l}$ is within a site, then tensile strength is set normally to the anisotropy plane:

$\Delta \varepsilon_{n}=-\delta$.

In terms of formulas (6) and (7), a value of deformation increase is determined in the process of step-bystep calculations. During step one it is defined as small value to compare with elastic deformation; then it is specified by means of its successive increment in terms of repetitive stress calculations until strength condition is met. Along with the increase in breaking deformations of shear and failure, strength decreases in terms of corresponding sites. The strength increase is calculated depending upon increments if breaking deformations of shear failure deformations take place.

Strength increment in terms of shear is:

$$
\Delta p_{n}=\left\{\begin{array}{l}
-\frac{M_{\gamma}}{1+K_{p l}}\left|\Delta \gamma_{n}^{p}\right| \text { if }\left|\gamma^{p}\right|<K_{p l}\left|\gamma^{e}\right| ; \\
-M_{\gamma}\left|\Delta \gamma_{n}^{p}\right| \text { if }\left|\gamma^{p}\right|>K_{p l}\left|\gamma^{e}\right| .
\end{array}\right.
$$

Strength increment in terms of failure is:

$\Delta p_{n}=M_{\varepsilon} \Delta \varepsilon_{n}$,

where:

$M_{\gamma}$ and $M_{\varepsilon}$ - local decay modules in terms of shear and tension respectively.

As distinct from decay module, used in rock mechanics (Petukhov \& Lin'kov, 1983) to determine a slope angle of stress-deformation line within a site beyond maximum, local decay modules describe connection between increments of breaking deformations and decreasing relative strength.

The oriented strength weakening within rocks is manifested in the anisotropy of deformation properties including elastic ones. Changes in elastic rock properties depend upon a degree of strength weakening in different directions - from fragmentation. The fragmentation degree may be estimated inclusive of the achieved degree of strength decrease; in this context, shear rigidity varies towards directions coinciding with directions of failure planes.

Stresses and strains are interconnected by means of Hook's law ratios; in the context of Cartesian coordinates, matrix form of the ratios is:

$\{\sigma\}=\left[D_{0}\right]\{\varepsilon\}$,

where:

$\{\sigma\}=\left\{\sigma_{x}, \sigma_{y}, \sigma_{z}, \tau_{x y}, \tau_{y z}, \tau_{z x}\right\}^{\dot{o}},\{\varepsilon\}=\left\{\varepsilon_{x}, \varepsilon_{y}, \varepsilon_{z}, \gamma_{x y}, \gamma_{y z}, \gamma_{z x}\right\}^{\dot{b}-}$ columns of stress and strain components;

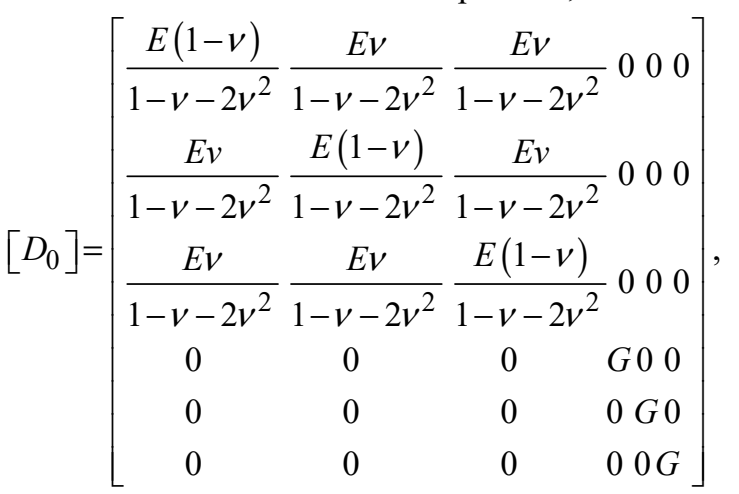


where:

$$
\begin{aligned}
& E \text { - Young's modulus; } \\
& v \text { - Poison's ratio; } \\
& G \text { - shear module. }
\end{aligned}
$$

Relying upon the fact that shear flexibility (including elastic flexibility) is the most important manifestation of rock fissuring and laminarity, rock layers can be considered as isotropic for axial strains with the pronounced shear anisotropy along formation lines or laminal formations resulting from fracture networks.

In the context of medium with shear anisotropy, stiffness matrix can be represented as that consisting of two parts: leading matrix (11) and additional matrix, determining the effect of the oriented rigidity weakening:

$$
[D]=\left[D_{0}\right]-G\left[K_{g}\right]
$$

In terms of axial symmetry for a medium with weakening along the directions with $\pi / 4$ step, $[D]$ matrix is:

$$
\begin{gathered}
{[D]=\frac{E}{(1-2 v)(1-v)}\left[\begin{array}{cccc}
1-v & v & v & 0 \\
v & 1-v & v & 0 \\
v & v & 1-v & 0 \\
0 & 0 & 0 & \frac{1-2 v}{2}
\end{array}\right],} \\
-G\left[\begin{array}{cccc}
\delta_{66} & 0 & 0 & 0 \\
0 & \delta_{77} & -\delta_{34} & 0 \\
0 & -\delta_{34} & \delta_{66} & 0 \\
0 & 0 & 0 & \delta_{12}
\end{array}\right],
\end{gathered}
$$

where:

$$
\begin{aligned}
& \delta_{12}=1-\frac{k_{1} k_{2}}{1-\left(1-k_{1}\right)\left(1-k_{2}\right)} ; \\
& \delta_{34}=1-\frac{k_{3} k_{4}}{1-\left(1-k_{3}\right)\left(1-k_{4}\right)} ; \\
& \delta_{66}=1-\frac{k_{6} k_{6}}{1-\left(1-k_{6}\right)\left(1-k_{6}\right)} ; \\
& \delta_{77}=1-\frac{k_{7} k_{7}}{1-\left(1-k_{7}\right)\left(1-k_{7}\right)} .
\end{aligned}
$$

$k_{1}, \ldots, k_{7}$-parameters determining changes in shear stiffness along corresponding directions (Fig. 2).

Parameters, characterizing changes in elastic shear stiffness in terms of different directions depend upon the degree of strength weakening. Following dependence of the shear stiffness weakening parameter on the weakening parameter along corresponding directions has been taken:

$$
k_{i}=1-\left(1-p_{i}\right)^{m}
$$

It is taken in calculations that $m=4$ (the value has been taken on the basis of comparison of the measured and calculated basin curves of the Earth's surface displacement within the stratified deposit).

Loading velocity is very important for the results of the sample tests. Despite the fact that standard sample tests in terms of uniaxial loading take several minutes, viscous properties effect loading diagrams. A model of elastic-viscous-elastic body, containing two elements of
Kelvin-Voigt, is applied to simulate viscous properties. A velocity of elastic-viscous deformation components is described with the help of the ratio:

$$
\dot{\varepsilon}^{v e}=\theta_{1}^{-1}\left(\varepsilon_{¥}^{(1)}(\sigma)-\varepsilon_{1}^{v e}\right)+\theta_{2}^{-1}\left(\varepsilon_{¥}^{(2)}(\sigma)-\varepsilon_{2}^{v e}\right) .
$$

where addends one and two describe stage one (i.e. quick) and stage two (i.e. slow) of viscous-elastic deformation;

$\varepsilon_{1}{ }^{\text {ve }}$ and $\varepsilon_{2}{ }^{\text {ve }}$ - viscous-elastic deformations of stages one and two;

$\theta_{1}$ and $\theta_{2}-$ delay time;

$\varepsilon_{\infty}^{(1)}(\sigma)$ and $\varepsilon_{\infty}^{(2)}(\sigma)$ - ultimate viscous-elastic deformations during infinite time being determined as shares of elastic deformation.

Taking into consideration the relations between stresses and elastic deformations, elastic-viscous deformations for infinite time are determined as shares of elastic deformation:

$\varepsilon_{\infty}^{v e}=k_{v e} \varepsilon^{e}$,

where:

$k_{v e}$-elastic viscosity coefficient determining ratio limit between elastic-viscous and elastic shear deformation in terms of steady loading (Olovyannyy, 2012; Olovyannyy, 2016).

Viscous deformations are considered to be incompressible in terms of Cartesian coordinates:

$\varepsilon_{1}^{v e}+\varepsilon_{2}^{v e}+\varepsilon_{3}^{v e}=0$.

Viscous-elastic deformations are the sum of viscouselastic and breaking deformations requiring no specific description. Volume changes with time are determined with the help of effects of plastic deformation and failure.

According to the values of stresses and strains, obtained within the step for each element, increment of plastic (breaking) shear deformations and rupturing deformations as well as strength increment in terms of each of the separated directions are calculated. Following step involves calculations inclusive of increment of additional forces within nodes of the network of elements determined relying upon increments of nonelastic deformations; potential failures are controlled with the consideration of the strength experienced its variations depending upon the directions.

Degradation index $p_{n}$ is estimated within each component of the medium in terms of all possible failure planes. Its idea is similar to a weakening coefficient applied by rock mechanics (Fisenko, 1976). The differrence is that the weakening coefficient determines strength decrease in the mean as isotropic parameter; as for $p_{n}$ parameter, it is determined on the oriented directions within each point of the object rock mass.

\section{MATHEMATICAL MODELING OF THE SAMPLE TESTS IN TERMS OF UNIAXIAL LOADING}

Cylindrical samples were tested in terms of uniaxial loading to determine such deformation and strength parameters as compression strength, elasticity modulus, Poison's ratio, dip modulus, and residual strength. In 
terms of volumetric stress, and strain, viscous parameters are determined on the results of sample tests under adequate loading conditions.

When pressure is put on a sample within the sample contact surfaces and the press plates, friction forces arise resulting in the disturbance of a stress state uniformity. "High" samples are used to reach maximum uniformity of stress distribution; as a rule, it is done when heightdiameter ratio is equal to two or more. However, under real conditions, uniform state cannot be reached; while compressing, a sample becomes of a barrel shape and breaking process takes place with the formation of uniformity loss zones. Most of all, the zones are conical.

Proper boundary conditions are established when sample deformation modeling at the surfaces of the sample contact the press plates. Complete sample-press plate adhesion in the context of mathematical modeling corresponds to real conditions within contacts.

A stage of sample failure involves deviation of the process from axial symmetry. Complete sample failure happens on the flat surfaces. Axial symmetry is preserved at any modeling stage; thus, it is impossible to simulate formation of such surfaces.

Argillous sample deformation has been modeled as an example. Height-diameter ratio of cylindrical samples is equal to two (Fig. 3). Conditions of complete adhesions with rigid press plates are set within a contact of the sample end faces (radial displacements are inhibited in each point of the contact). A process of the sample deformation and failure under axial loading with periodical unloading in terms of constant deformation velocity is calculated.

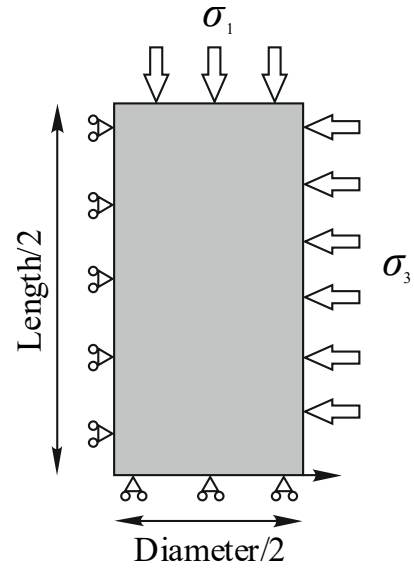

Figure 3. Calculation model of a cylindrical sample

Radial displacements are inhibited along the sample axis; and vertical displacements are inhibited along the surface of a midsection. Radial displacements of nodes are inhibited within sample-press plate contact; a displacement is set when velocity of the sample axial deformation is 0.015 hour $^{-1}$.

Modeling results for three argillous samples (V.V. Sokurov, T.Yu. Vekshina, and Yu.V. Zaitsev) have been quoted; they were sampled from different depths (Fig. 4). Parameters of deformation and strength properties are determined by means of selection subject to the best coincidence of calculation graph and laboratory graph of axial strain-pressure on the sample connection; basic parameters are in Table 1.

Table 1. Basic parameters of deformation and strength rock properties within the samples

\begin{tabular}{|c|c|c|c|c|c|c|c|c|c|c|}
\hline 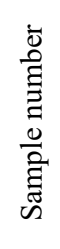 & 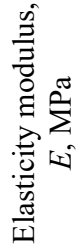 & 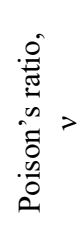 & 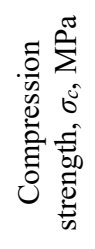 & 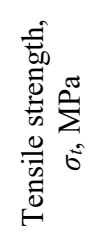 & 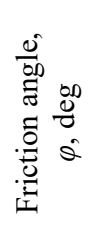 & 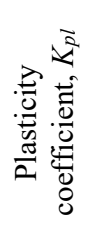 & 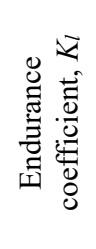 & 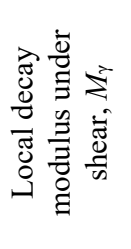 & 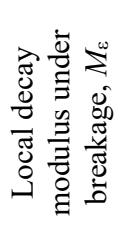 & 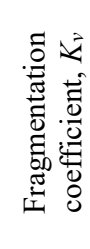 \\
\hline 7 & 18 & 0.20 & 0.15 & 0.012 & 15.0 & 6.50 & 0.65 & 6.5 & 4.5 & 0.240 \\
\hline 17 & 48 & 0.24 & 1.60 & 0.090 & 12.0 & 0.10 & 0.45 & 22.0 & 14.0 & 0.008 \\
\hline 18 & 49 & 0.16 & 0.25 & 0.030 & 11.4 & 0.24 & 0.61 & 7.2 & 11.5 & 0.050 \\
\hline
\end{tabular}

*The table does not contain the parameters characterizing viscosity

The obtained stress-axial strains graphs being a result of numerical modeling are close to the graphs obtained as a result of laboratory tests. Experimental graph of side strains has not been recorded within the series. Graphs in Figure 4 represent all substantial behavioural features of rocks demonstrating themselves in the process of such tests. The modeling results not only correspond to the common concepts of failure processes; they also give additional information concerning the phenomena character and order.

Another important fact should be noted. The parameters of deformation and strength properties which made it possible to develop a diagram (coinciding accurately with experimental dependence) while modeling, were obtained on the results of one sample testing. In this context, if, for example, other strength values under tension are taken instead of the above-mentioned, then design graphs will differ from experimental ones. The same is true for any deformation and strength parameters to be explained by the fact that certain sample parts experience different conditions of compression, tension, and displacement; thus, the model parameters, involved in the process of deformation and failure description under such conditions, effect the modeling results. It means that elastic characteristics, compression and tensile strength, adhesion, friction angle, endurance, fraction coefficient, and other parameters demonstrate themselves under uniaxial compression; hence, it is possible to determine them according to the results of one sample testing.

The modeling demonstrates clearly that a value of peak pressure on the sample is not equal to $\sigma_{c}$ depending upon shear strength parameters $C$ and $\varphi$ in the context of the taken model:

$\sigma_{c}=2 C \frac{\cos \phi}{1-\sin \phi}$

when the peak pressure on the sample also depends on other parameters especially those characterizing fragmentation while shearing, brittleness, and plasticity. 
(a)

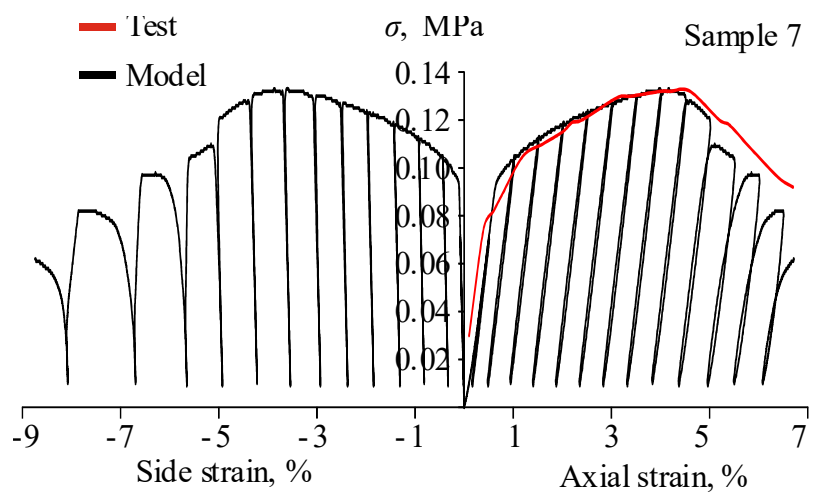

(b)

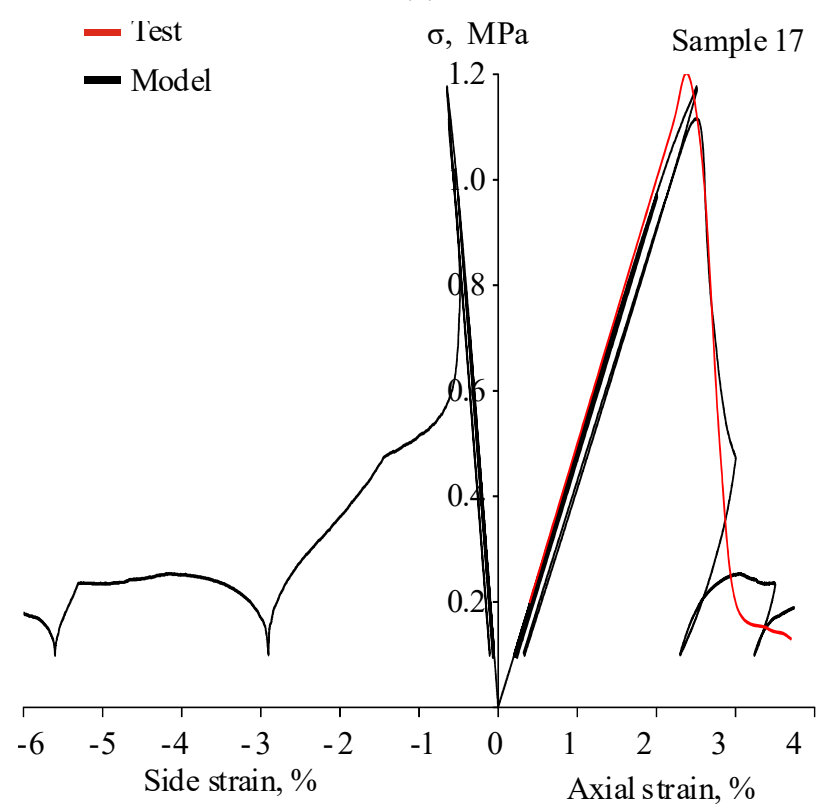

(c)

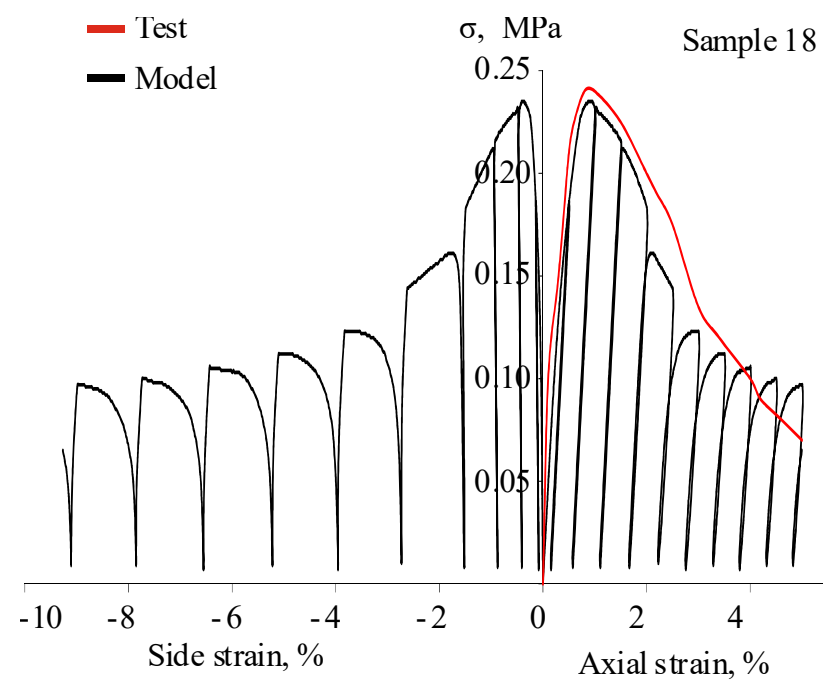

Figure 4. Diagrams of cylindrical samples loading: (a), (b), and (c) are samples 7, 17, and 18 respectively

On Figure 4 lateral strain reflects change in the sample radius midsection; the experiment took a cycle. Calculations were performed with periodical unloading.
Figure 5 demonstrates sample 17 section of the initial shape and the shape deformed after the modeling terminated when weakness zones, where strength loose was more than $90 \%$ of the initial one, made a junction dividing the sample into parts. Strokes in Figure 5 mean orientation of circular surfaces over which strength loss takes places. $D$ line, drawn along failure zones identified by the modeling within the sample midsection (Fig. 5b), corresponds to a fracture pattern at the sample surface (Fig. 5a).

(a)

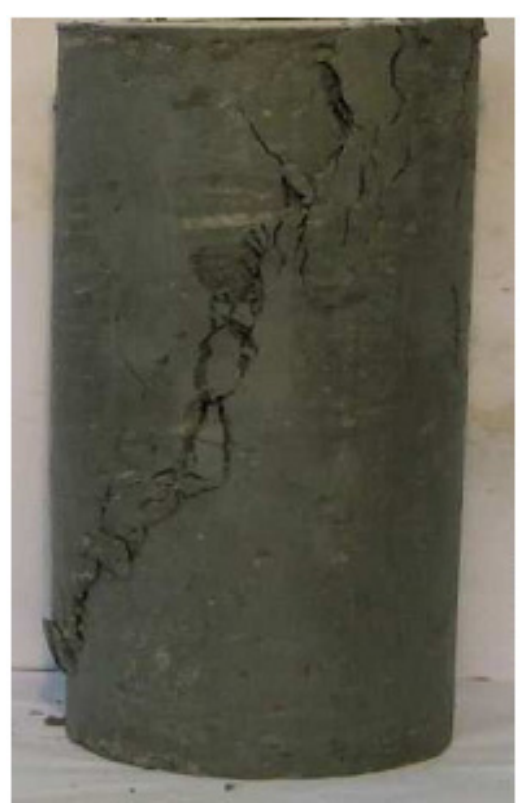

(b)

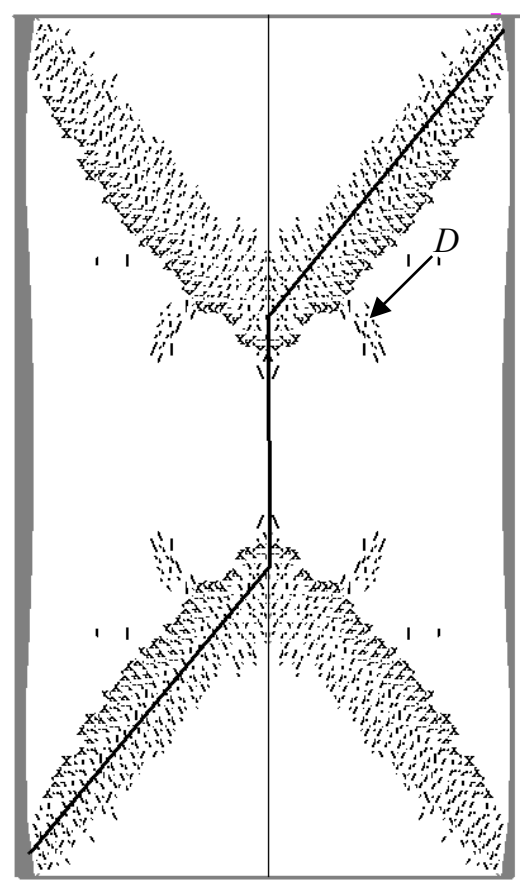

Figure 5. Argillous sample at the end of loading process (a) and a patterns of the calculated disturbances within diametric section (b); $D$ - a line of potential sample breaking within a midsection (the line is drawn on the calculated disturbance zones) 
Mathematical modeling if rock samples tests makes it possible to see the failure process development when axial strain increases.

Laboratory tests involve construction of graphs of axial strains and side strains of a sample. If mathematical model is adequate reflecting basic regularities of the material deformation and failure, then it is possible to select such parameters helping obtain reasonable coincidence of design graphs and laboratory graphs.

Coincidence of design graphs and laboratory graphs means that for the most part the model, being used, reflects correctly regularities of the sample deformation and failure.

Nonlinear section is observed within the initial part of axial strain graph of rock salt sample (Fig. 1). The section demonstrates effect on deformations of microdefects, i.e. pores and microfissures. It is obvious that the microdefects effect on the sample behaviour during following deformation and failure stages. We believe that the loading velocity effect on the sample tests depends primarily on viscous properties of the microdefects.

Hence, the deformation and failure model, involving such components as elastic, plastic, viscous, and breaking parts, should also involve microdefect component of rock sample disturbance.

\section{MICRODEFECT MODEL}

Stresses-deformations dependence graph (Fig. 1) includes nonlinear section at the very initial loading stage indicating that microdefects (i.e. microfissures and pores) are available within rocks; the microdefects have impact of the disturbed rocks in the loading process. Form of the initial section is indicative of low inelasticity of the microdefects to compare with original material.

Behaviour of the medium under deformation may be represented in the form of a graph where deformation modulus is lower within tension area to compare with compression area where it increases nonlinearly (Fig. 6).

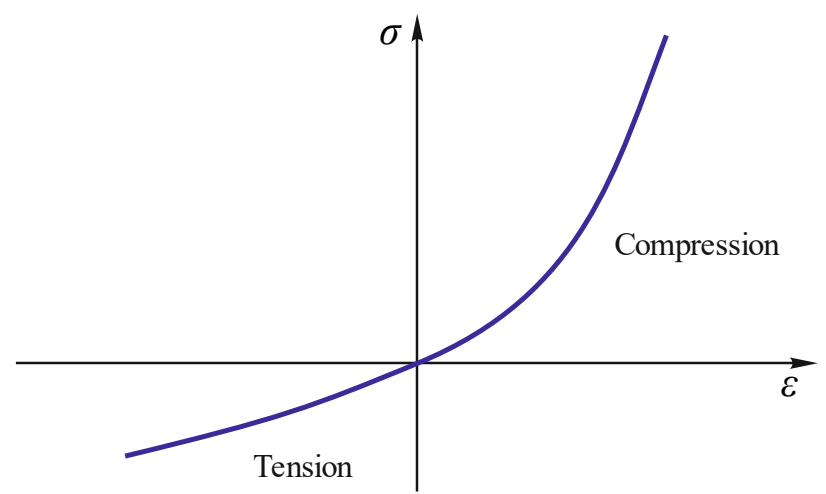

Figure 6. Schematic deformation graph of microdefect component of rock model in terms of tension and compression

There are two approaches to consider the effect of microdefects on rock deformation and failure: effect of the microdefects as nonhomogeneity of strength and other elastic properties distributed within solid material randomly (Tang, Liu, Lee, Tsui, \& Tham, 2000; Tang, Tham, Lee, Tsui, \& Liu, 2000; Ma, Wang, \& Ren, 2011;
Hamdi, Stead, \& Elmo, 2015). The random nonhomogeneity is introduced to open potential breakdown sites. In the context of such an approach, initial nonlinear section of loading diagram is not demonstrated.

Approach two takes into consideration effect of pores and fissures as cavities distributed within the solid material (Shen \& Shao, 2017). The approach makes it possible to achieve coincidence of diagrams, basing upon constitutive models, and experimental data for rock samples.

The paper proposes phenomenological model considering effect of microdefects as the additional factor effectting rock disturbance. The model relies upon comparison of design graphs and experimental graphs in the process of mathematical modeling to test specific rock samples.

Properties of the medium are: microdefect medium is viscous; its manifestations depend heavily on loading velocity; deformations are reversible; and the deformations are local.

Microdefect medium can be described with the help of following expressions:

- velocity of viscous-elastic deformations towards basic deformations is:

$d \varepsilon_{i}^{v e}=\left(\ni_{i}-\varepsilon_{m d}^{i}\right)\left[1-\exp \left(-\eta_{m d} d t\right)\right]$,

where:

$\exists_{i}$ - ultimate compression deformation in terms of the current stress level;

$\varepsilon_{m d}^{i}$ - the achieved deformation level;

$\eta_{m d}-$ a coefficient of the microdefect viscosity;

- within the space of the basic deformation we have:

$$
\ni_{i}=\left\{\begin{array}{l}
\frac{\left[1-\left(1-\frac{E_{m d}}{E}\right)\right] \frac{\varepsilon_{m d}^{i}}{e_{m d}}}{E_{m d}}\left[\sigma_{i}-v\left(\sigma_{j}+\sigma_{k}\right)\right] \text { if } \varepsilon_{m d}^{i}>0 ;(20) \\
\frac{1}{E_{m d}}\left[\sigma_{i}-v\left(\sigma_{j}+\sigma_{k}\right)\right] \text { if } \varepsilon_{m d}^{i}<0 .
\end{array}\right.
$$

where:

$e_{m d}$ - peak compression deformation;

$E$ - elasticity modulus;

$E_{m d}$ - elasticity modulus of the microdefect medium under tension.

The modeling process has shown that certain share of lateral deformations within the sample midsection can be explained by failure dilatancy as well as opening (closure) of fissures. The model does not describe plastic deformation of failure in the neighbourhood of microdefects as it is proposed by (Shen \& Shao, 2017). The microdefects including pores and microfissures contribute significantly to deformation process during all loading stages together with the stage when the sample is being broken not explicitly.

\section{MODELING OF SALT ROCK SAMPLES}

One and the same models with different parameters describe elastic, plastic, brittle, and viscous differences of rocks. Parameters of rock state equations are determined relying upon laboratory tests of several samples belonging to one homogeneous rock block. It is supposed that the average parameters, obtained with the help of different samples, may be attributed to the whole block. 
Laboratory experiments are carried out under different conditions of sample loading: under uniaxial and isotropic compression; under tension; and under the conditions of steady loading. Each loading type is meant for the determination of different parameters.

Resulting from the laboratory tests of the sample, graphs are constructed to contact acting power experimental parameters, time parameters, and deformation parameters. Graphs are also constructed as a consequence of the sample mathematical modeling for the conditions of the experiment with the specified input parameters. Qualitative coincidence or difference in experimental graphs and design graphs as well as a possibility to reach their reasonable coincidence in terms of the varied state equations confirms the accepted model adequacy (i.e. state equations).

Test of cylindrical sample under uniaxial compression with the specified constant velocity of axial deformation down to the sample complete breakage is the most popular technique to study rock properties. Generally, slipping is not available within the contacts between end surfaces of the samples and press plates. In the context of mathematical modeling, boundary conditions of horizontal displacements inhibition within the sample ends are adequate to such conditions. In terms of the loading conditions, nonhomogeneous stress field arises within the sample. In proportion to the increase in axis compression deformations, oriented weakening starts within the sample. While accumulating, it results in its breakage. Since stress fields and breakage fields are not uniform within the sample, different stress zones of uniaxial and volumetric compression, tension, and shear originate in its different parts. The zones demonstrate regularities of elastic anisotropy, plastic deformation, and breakage. It means that in the process of the mathematical deformation modeling all parameters of models of breakage as well as elastic, plastic, and viscous deformation become apparent.

Consider the problem solution in terms of the results concerning tests of sylvinite and rock salt samples (Fig. 7) (M.D. Iliinov, V.A. Korshunov, D.N. Petrov). The samples with $100 \mathrm{~mm}$ height and $50 \mathrm{~mm}$ diameter were tested at $0.05 \mathrm{~mm} / \mathrm{min}$ constant velocity of axial deformation.

Design parameters of the model are given in the Table 2. (a)

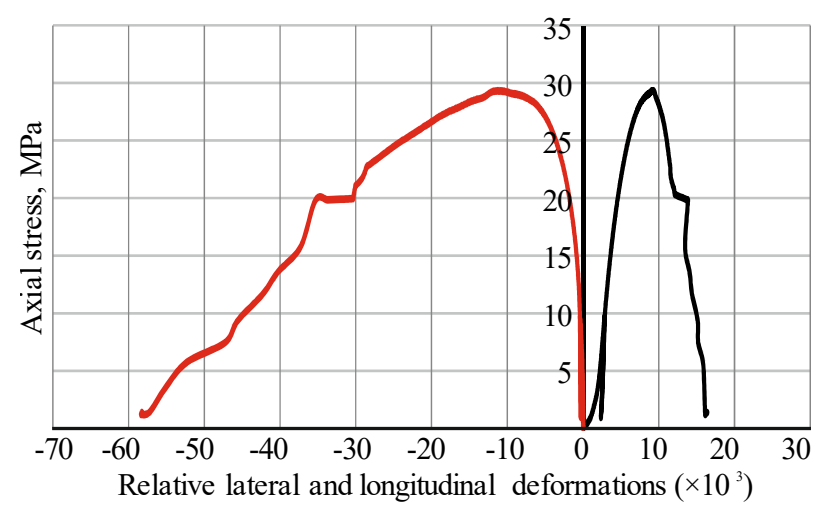

(b)

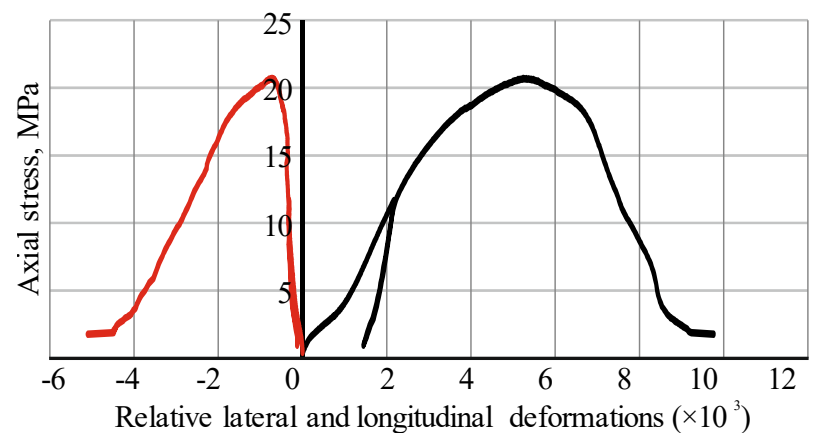

(c)

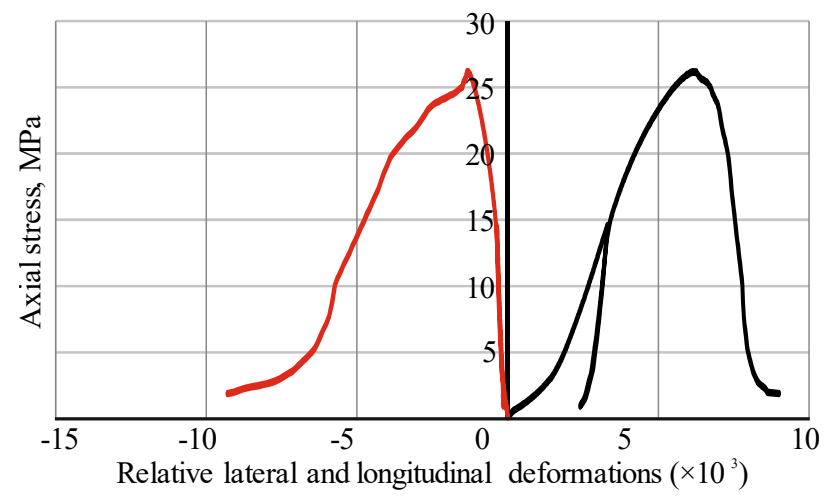

Figure 7. Deformation graphs resulted from sylvinite sample test (a) and rock salt test (b) and (c)

Table 2. Design parameters of the model

\begin{tabular}{|c|c|c|c|c|}
\hline \multirow{2}{*}{ Model parameters } & \multirow{2}{*}{ Measurement unit } & \multicolumn{3}{|c|}{ Rocks } \\
\hline & & Sylvinite & Rock salt (a) & Rock salt (b) \\
\hline Elasticity modulus & $\mathrm{MPa}$ & 5940 & 6415 & 7940 \\
\hline Poison's ratio & c.u. & 0.268 & 0.029 & 0.108 \\
\hline Compression strength & $\mathrm{MPa}$ & 24.0 & 19.6 & 19.6 \\
\hline Tension strength & $\mathrm{MPa}$ & 1.44 & 2.11 & 1.94 \\
\hline Frictional angle & deg & 24.0 & 26.7 & 33.0 \\
\hline Durability coefficient & c.u. & 0.60 & 0.63 & 0.50 \\
\hline Elasticity coefficient & c.u. & 2.05 & 1.48 & 1.23 \\
\hline Local decay modulus under shear & c.u. & 36.0 & 106.5 & 131.8 \\
\hline Local decay module under breakage & c.u. & 66.0 & 78.3 & 109.1 \\
\hline Expansion coefficient & c.u. & 1.32 & 0.09 & 0.78 \\
\hline$k_{v e}$ & c.u. & 3.5 & 3.2 & 2.2 \\
\hline$\theta_{1}^{-1}$ & hour $^{-1}$ & 0.098 & 0.088 & 0.088 \\
\hline$\theta_{2}^{-1}$ & hour $^{-1}$ & 0.0020 & 0.0018 & 0.0018 \\
\hline Peak potential deformation of microdefect compression & $\%$ & 0.105 & 0.050 & 0.121 \\
\hline Deformation modulus of microdefects & $\mathrm{MPa}$ & 873 & 492 & 767 \\
\hline Microdefect viscosity coefficient & hour $^{-1}$ & 14000 & 11000 & 12000 \\
\hline
\end{tabular}


The graphs, represented in Figure 8, confirm closeness of experimental and design curves both for axial and side deformations.

(a)

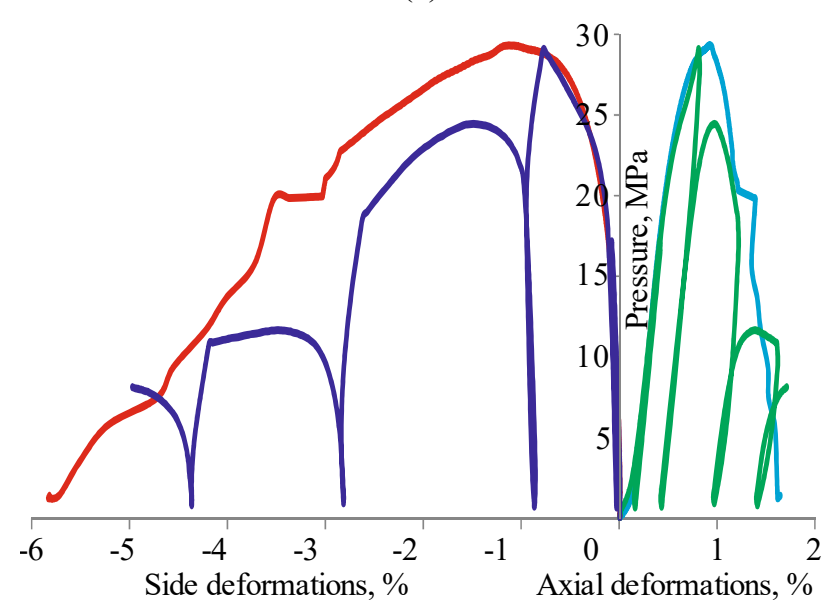

(b)

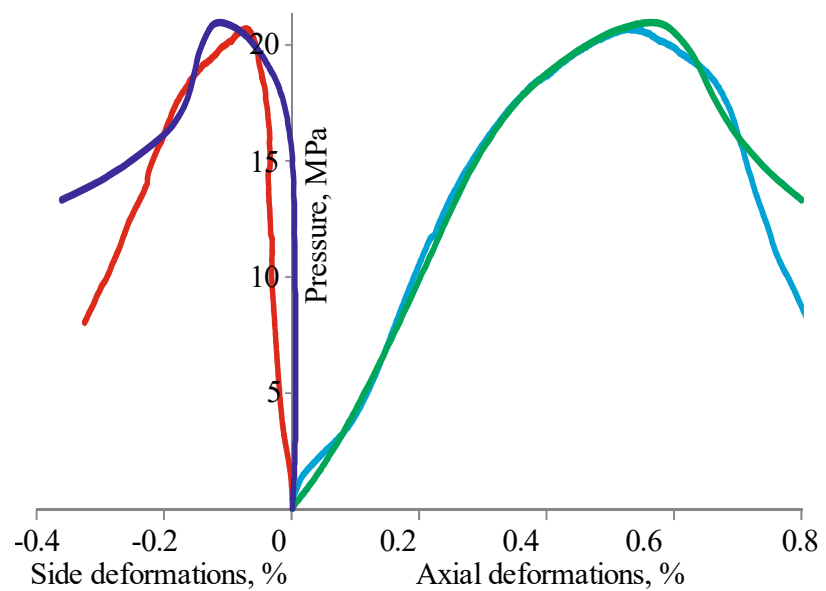

(c)

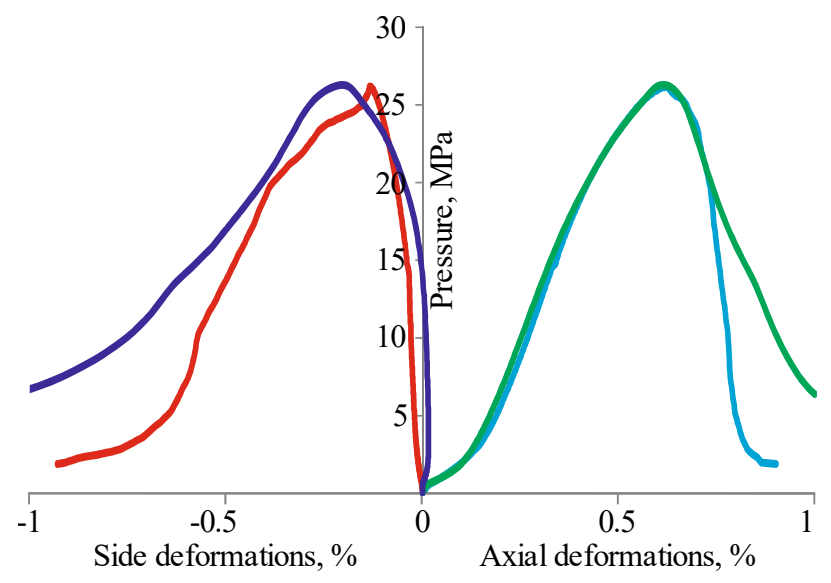

Figure 8. Deformation graphs of cylindrical samples resulting from test and mathematical modeling: sylvinite (a) and rock salt (b) and (c); side (test); $\longrightarrow$ axis (model); side (model)

The example of sylvinite sample loading with constant side pressure (Fig. 9) has shown qualitative coincidence of the graphs with the experimental results.

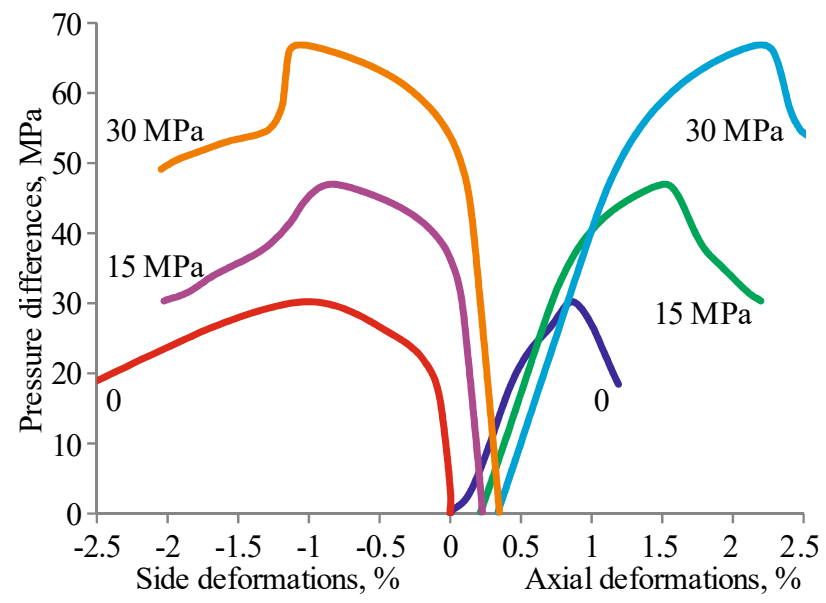

Figure 9. Design graphs of sylvinite cylindrical samples under uniaxial compression with constant side pressure

It should be noted that deformation value within the initial points diverges from zero resulting from volumetric compression of microdefects.

\section{CONCLUSIONS}

Finite-element model of breakable rocks is applied to simulate behaviour of rock samples under axial compression. In the context of the model, elements of disturbed medium are calculated as solid ones with anisotropic deformation and strength properties. Failure is considered as shear and failure strength decrease along the planes of the element anisotropy. Within each point of the medium (if finite-element method is applied, then within each element) the limited number of planes of possible failure with $45^{\circ}$ step is considered since they are required to estimate potential failure resulting from shear or tension stresses. It should be done at each loading stage. Strength decrease is followed by corresponding breaking deformations. In terms of sites, potential failure is determined with the help of Coulomb-Mohr criteria and tension strength.

Nonlinear part is observed at the initial section of axial deformation graphs resulting from the tests of rock salt and sylvinite samples. The part demonstrates the effect of deformation of microdefects. To get coincidence of design and experimental graphs, the model concerning behaviour of medium with microdefects, including pores and microfissures, has been adopted. Phenomenological model describing deformation of the microdefects of a medium with nonlinearly elastic and viscous properties and with the limited compressive deformations has been proposed. The modeling has shown that certain share of lateral deformations can be explained by both dilatancy in the breaking process and deformation of opening (closure) of microfissures. The microfissures, including pores and microfissures, are important for the process of rock deformation and failure. In the process of a sample deformation, microdefects arise not only within the initial nonlinear deformation part but also within each stage of the sample loading including that after peak pressure.

General model consists of fifteen parameters determining elastic, plastic, viscous, and brittle rock properties as well as deformation properties of a medium with microdefects. 
Stress-deformation diagrams, resulting from the mo-deling, describe observable (in terms of the experiments) features of sample behaviour during different deformation stages (i.e. nonlinear character before peak loading, decay while breaking, residual strength, hysteresis loops in terms of cyclical loading).

In the context of the examples, the calculated diagrams of sample tests coincide adequately with stressdeformation relation graphs obtained after laboratory compression tests. The modeling has shown that strength weakening on the oriented directions within the numerical experiments corresponds to the sample fragmentation between plates of laboratory press.

Stress field, being formed within the sample, is not uniform due to the effect of contacts between the sample ends and the press plates. During the deformation process, zones of different-component compression and tension with various disturbance degrees arise in different areas. Modeling of the processes is adequate if only they are described in such a manner reflecting basic regularities including deformation of microdefects. Coincidence of laboratory and design graphs of sample tests in terms of uniaxial compression is possible when all model parameters are selected properly including tensile strength and characteristics of volumetric adhesion failure, friction angle, and dilatancy. A method to select parameters is based upon minimization of deviation of experimental and design graphs connecting axial deformation and pressure on a sample and side deformations.

\section{ACKNOWLEDGEMENTS}

The studies have been supported by the Institute of environmental Geology of the Russian Academy of Sciences (St. Petersburg Faculty of the Geo-Ecological Institute).

The materials with the results of laboratory tests of rocks have been provided by "Steady-state analysis of ground" laboratory in "VNIIG im. B.E. Vedeneieva" Ltd (V.V. Sokurov, T.Yu. Vekshina, Yu.V.Zaitsev) and research laboratory of physical and mechanical properties and failure of rocks of St. Petersburg Mining University (M.D. Ilinov, Cand. Sc. (Engineering), V.A. Korshunov, Cand. Sc. (Engineering), D.N. Petrov, Cand. Sc. (Engineering)).

\section{REFERENCES}

Chiarelli, A.S., Shao, J.F., \& Hoteit, N. (2003). Modeling of elastoplastic damage behavior of a claystone. International Journal of Plasticity, 19(1), 23-45. https://doi.org/10.1016/s0749-6419(01)00017-1

Cox, S.J.D., \& Meredith, P.G. (1993). Microcrack formation and material softening in rock measured by monitoring acoustic emissions. International Journal of Rock Mechanics and Mining Sciences \& Geomechanics Abstracts, 30(1), 11-24. https://doi.org/10.1016/0148-9062(93)90172-a

Fadeev, A.B. (1987). Metod konechnykh elementov v geomekhanike. Moskva: Nedra.

Fang, Z., \& Harrison, J.P. (2002). Development of a local degradation approach to the modelling of brittle fracture in heterogeneous rocks. International Journal of Rock Mechanics and Mining Sciences, 39(4), 443-457. https://doi.org/10.1016/s1365-1609(02)00035-7
Fisenko, G.L. (1976). Predel'noe sostoyanie gornykh porod vokrug vyrabotok. Moskva: Nedra.

Hamdi, P., Stead, D., \& Elmo, D. (2015). Characterizing the influence of stress-induced microcracks on the laboratory strength and fracture development in brittle rocks using a finite-discrete element method-micro discrete fracture network FDEM- $\mu$ DFN approach. Journal of Rock Mechanics and Geotechnical Engineering, 7(6), 609-625. https://doi.org/10.1016/j.jrmge.2015.07.005

Hoek, E., \& Brown, E.T. (1980). Empirical strength criterion for rock masses. Journal of the Geotechnical Engineering Division, 106(15715), 1013-1035.

Hoxha, D., Giraud, A., Homand, F., \& Auvray, C. (2007). Saturated and unsaturated behaviour modelling of MeuseHaute/Marne argillite. International Journal of Plasticity, 23(5), 733-766. https://doi.org/10.1016/j.ijplas.2006.05.002

Kartashov, Yu.M., Matveev, B.V., Mikheev, G.V., \& Fadeev, A.B. (1979). Prochnost' $i$ deformiruemost' gornykh porod. Moskva: Nedra.

Lee, Y.-K., \& Pietruszczak, S. (2008). Application of critical plane approach to the prediction of strength anisotropy in transversely isotropic rock masses. International Journal of Rock Mechanics and Mining Sciences, 45(4), 513-523. https://doi.org/10.1016/j.ijrmms.2007.07.017

Lisjak, A., Figi, D., \& Grasselli, G. (2014). Fracture development around deep underground excavations: Insights from FDEM modelling. Journal of Rock Mechanics and Geotechnical Engineering, 6(6), 493-505. https://doi.org/10.1016/j.jrmge.2014.09.003

Lockner, D.A., Byerlee, J.D., Kuksenko, V., Ponomarev, A., \& Sidorin, A. (1991). Quasi-static fault growth and shear fracture energy in granite. Nature, 350(6313), 39-42. https://doi.org/10.1038/350039a0

Lydzba, D., Pietruszczak, S., \& Shao, J.F. (2003). On anisotropy of stratified rocks: homogenization and fabric tensor approach. Computers and Geotechnics, 30(4), 289-302. https://doi.org/10.1016/s0266-352x(03)00004-1

Ma, G.W., Wang, X.J., \& Ren, F. (2011). Numerical simulation of compressive failure of heterogeneous rock-like materials using SPH method. International Journal of Rock Mechanics and Mining Sciences, 48(3), 353-363. https://doi.org/10.1016/j.ijrmms.2011.02.001

Nova, R. (1980). The failure of transversely isotropic rocks in triaxial compression. International Journal of Rock Mechanics and Mining Sciences \& Geomechanics Abstracts, 17(6), 325-332. https://doi.org/10.1016/0148-9062(80)90515-x

Nur, A., \& Simmons, G. (1970). The origin of small cracks in igneous rocks. International Journal of Rock Mechanics and Mining Sciences \& Geomechanics Abstracts, 7(3), 307-314. https://doi.org/10.1016/0148-9062(70)90044-6

Olovyannyy, A.G. (2003). Nekotorye zadachi mekhaniki gornykh porod. Sankt-Petergurg: Stress.

Olovyannyy, A.G. (2012). Mekhanika gornykh porod. Modelirovanie razrusheniy. Sankt-Petergurg: Kosta.

Olovyannyy, A.G. (2016). Gravitatsionnye i tektonicheskie napryazheniya v massive gornykh porod. Gornyy Zhurnal, (4), 25-31.

Pan, X.D., \& Hudson, J.A. (1989). Simplified three dimensional Hock-Braun yield criterion. International Journal of Rock Mechanics and Mining Sciences \& Geomechanics Abstracts, 26(2), 95-103. https://doi.org/10.1016/0148-9062(89)90069-7

Pariseau, WG. (1968). Plasticity theory for anisotropic rocks and soils. Proceedings of the $10^{\text {th }}$ Symposium on Rock Mechanics, 267-295. 
Pells, P.J.N. (1993). Uniaxial strength testing. Rock Testing and Site Characterization, (3), 67-85. https://doi.org/10.1016/B978-0-08-042066-0.50010-0

Petukhov, I.M., \& Lin'kov, A.M. (1983). Mekhanika gornykh udarov $i$ vybrosov. Moskva: Nedra.

Pietruszczak, S., \& Mroz, Z. (2001). On failure criteria for anisotropic cohesive-frictional materials. International Journal for Numerical and Analytical Methods in Geomechanics, 25(5), 509-524. https://doi.org/10.1002/nag.141

Shao, J.F., Jia, Y., Kondo, D., \& Chiarelli, A.S. (2006). A coupled elastoplastic damage model for semi-brittle materials and extension to unsaturated conditions. Mechanics of Materials, 38(3), 218-232. https://doi.org/10.1016/j.mechmat.2005.07.002

Shen, W.Q., \& Shao, J.F. (2017). Some micromechanical models of elastoplastic behaviors of porous geomaterials. Journal of Rock Mechanics and Geotechnical Engineering, 9(1), 1-17. https://doi.org/10.1016/j.jrmge.2016.06.011

Stavrogin, A.N., \& Tarasov, B.G. (1992). Eksperimental'naya fizika i mekhanika gornykh porod. Sankt-Petergurg: Nauka.

Tang, C., Liu, H., Lee, P.K., Tsui, Y., \& Tham, L. (2000). Numerical studies of the influence of microstructure on rock failure in uniaxial compression - Part I: effect of heterogeneity. International Journal of Rock Mechanics and Mining Sciences, 37(4), 555-569.

https://doi.org/10.1016/s1365-1609(99)00121-5
Tang, C., Tham, L., Lee, P.K., Tsui, Y., \& Liu, H. (2000). Numerical studies of the influence of microstructure on rock failure in uniaxial compression - Part II: constraint, slenderness and size effect. International Journal of Rock Mechanics and Mining Sciences, 37(4), 571-583. https://doi.org/10.1016/s1365-1609(99)00122-7

Unteregger, D., Fuchs, B., \& Hofstetter, G. (2015). A damage plasticity model for different types of intact rock. International Journal of Rock Mechanics and Mining Sciences, (80), 402-411. https://doi.org/10.1016/i.ijrmms.2015.09.012

Walsh, J.B., \& Brace, W.F. (1964). A fracture criterion for brittle anisotropic rock. Journal of Geophysical Research, 69(16), 3449-3456. https://doi.org/10.1029/jz069i016p03449

Wawersik, W.R., \& Fairhurst, C. (1970). A study of brittle rock fracture in laboratory compression experiments. International Journal of Rock Mechanics and Mining Sciences \& Geomechanics Abstracts, 7(5), 561-575. https://doi.org/10.1016/0148-9062(70)90007-0

Wawersik, W.R., \& Brace, W.F. (1971). Post-failure behavior of a granite and diabase. Rock Mechanics \& Rock Engineering, 3(2), 61-85. https://doi.org/10.1007/bf01239627

\section{МОДЕЛЮВАННЯ ВИПРОБУВАННЯ ЗРАЗКІВ ПРИ СТИСКУ ЗА ДОПОМОГОЮ СКІНЧЕННО-ЕЛЕМЕНТНОЇ МОДЕЛІ ГІРСЬКИХ ПОРІД, ЩО РУЙНУЮТЬСЯ}

\section{А. Олов'яний, В. Чанцев}

Мета. Розробка математичної моделі, яка описує характер процесу руйнування глинистих і соляних зразків при їх випробуванні на стиск, а також наявності мікродефектів на основі методу скінченних елементів.

Методика. Для моделювання поведінки циліндричних зразків гірських порід в умовах осьового стиску застосовується скінченно-елементна модель гірських порід, що руйнуються. У прийнятій моделі елементи середовища 3 порушенням цілісності розраховуються як суцільні з анізотропними деформаційними та міцнісними властивостями. Руйнування розглядається як зниження міцності на зсув і розрив за площинами анізотропії елемента. У кожній точці середовища (при розрахунку методом кінцевих елементів - у кожному елементі) розглядається обмежена кількість площин можливого руйнування із кроком $45^{\circ}$, за якими на кожному етапі навантаження оцінюється можливість руйнування від дії зсувних або розтягальних напружень, що розтягують. Можливість руйнування по майданчиках визначається за допомогою критеріїв Кулона-Мора й міцності при розтягуванні.

Результати. Встановлено, що за допомогою математичного моделювання представляється можливим проводити спостереження за процесом розвитку порушень у зразку. Діаграми напружень - деформації, отримані при моделюванні, показують особливості поведінки зразків на різних етапах навантаження (нелінійний характер до максимального навантаження, спад при руйнуванні, залишкова міцність, гістерезисні петлі при циклічному навантаженні). Доведено, що при відповідному підборі параметрів моделі вдається домогтися прийнятного збігу розрахованих і лабораторних кривих, що описують зв'язок осьових та бічних деформацій з тиском на зразки суглинку, сильвініту й кам'яної солі.

Наукова новизна. Розроблено скінченно-елементна модель, що дозволяє описувати процеси деформування й руйнування зразків гірських порід при випробуванні у лабораторних умовах і відрізняється тим, що доповнена описанням процесів деформування мікротріщин і пор.

Практична значимість. В результаті виконання моделювання методом скінченних елементів гірських порід, що руйнуються, досягається збіг з прийнятною точністю розрахованих діаграм випробувань зразків із графіками зв'язку між напруженнями і деформаціями, отриманими при випробуваннях в лабораторних умовах. Отримані позитивні результати свідчать про можливість застосування скінченно-елементної моделі деформування і руйнування гірських порід у задачах гірського тиску.

Ключові слова: гірська порода, зразки, деформування, руйнування, деформація пор, математичне моделювання, метод скінченних елементів 


\section{МОДЕЛИРОВАНИЕ ИСПЫТАНИЯ ОБРАЗЦОВ ПРИ СЖАТИИ С ПОМОЩЬЮ КОНЕЧНО-ЭЛЕМЕНТНОЙ МОДЕЛИ РАЗРУШАЮЩИХСЯ ГОРНЫХ ПОРОД}

\section{А. Оловянный, В. Чанцев}

Цель. Разработка математической модели, описывающей характер процесса разрушения глинистых и соляных образцов при их испытании на сжатие, а также наличия микродефектов на основе метода конечных элементов.

Методика. Для моделирования поведения цилиндрических образцов горных пород в условиях осевого сжатия применяется конечно-элементная модель разрушающихся горных пород. В принятой модели элементы среды с нарушением сплошности рассчитываются как сплошные с анизотропными деформационными и прочностными свойствами. Разрушение рассматривается как снижение прочности на сдвиг и разрыв по плоскостям анизотропии элемента. В каждой точке среды (при расчете методом конечных элементов - в каждом элементе) рассматривается ограниченное количество плоскостей возможного разрушения с шагом $45^{\circ}$, по которым на каждом этапе нагружения оценивается возможность разрушения от действия сдвиговых или растягивающих напряжений. Возможность разрушения по площадкам определяется с помощью критериев Кулона-Мора и прочности при растяжении.

Результаты. Установлено, что при помощи математического моделирования представляется возможным производить наблюдения за процессом развития нарушений в образце. Диаграммы напряжения - деформации, полученные при моделировании, показывают особенности поведения образцов на разных этапах нагружения (нелинейный характер до максимальной нагрузки, спад при разрушении, остаточная прочность, гистерезисные петли при циклическом нагружении). Доказано, что при соответствующем подборе параметров модели удается добиться приемлемого совпадения рассчитанных и лабораторных кривых, описывающих связи осевых и боковых деформаций с давлением на образцы суглинка, сильвинита и каменной соли.

Научная новизна. Разработана конечно-элементная модель, позволяющая описывать процессы деформирования и разрушения образцов горных пород при испытании в лабораторных условиях и отличающаяся тем, что дополнена описанием процессов деформирования микротрещин и пор.

Практическая значимость. В результате выполнения моделирования методом конечных элементов разрушающихся горных пород достигается совпадение с приемлемой точностью рассчитанных диаграмм испытаний образцов с графиками связи между напряжениями и деформациями, полученными при испытаниях в лабораторных условиях. Полученные положительные результаты свидетельствуют о применимости конечноэлементной модели деформирования и разрушения горных пород в задачах горного давления.

Ключевые слова: горная порода, образиы, деформирование, разрушение, деформация пор, математическое моделирование, метод конечных элементов

\section{ARTICLE INFO}

Received: 7 February 2018

Accepted: 20 June 2018

Available online: 20 July 2018

\section{ABOUT AUTHORS}

Anatoliy Olovyannyy, Candidate of Technical Sciences, Principal Researcher of the Saint-Petersburg Branch of the Federal State Budgetary Institution of Science of the Institute of Geoecology named after E.M. Sergeev of the Russian Academy of Sciences, 41 Srednii Ave., 190004, Saint-Petersburg, Russian Federation. E-mail: agolov@hgepro.ru

Valeriy Chantsev, Candidate of Physical and Mathematical Sciences, Associate Professor of the Institute of Industrial Management, Economics and Trade, Peter the Great Saint-Petersburg Polytechnic University, 29 Politekhnicheskaya St, 195251, Saint-Petersburg, Russian Federation. E-mail: chantsev.valery@gmail.com 